九州大学学術情報リポジトリ

Kyushu University Institutional Repository

\title{
Eutrophication Status of Lakes in Inner Hanoi and a Case Study of Cu Chinh Lake
}

\section{THUAN, Ta Dang}

Division of Environmental Engineering Technology, Faculty of Chemical and Environmental

Technology, Hung Yen University of Technology and Education

LAP, Bui Quoc

Division of Environmental Management, Faculty of Chemistry and Environment, Thuyloi University

THANH, Le Minh

HARADA, Masayoshi

Laboratory of Water Environment Engineering, Division of Bioproduction Environmental Sciences, Department of Agro-environmental Sciences, Faculty of Agriculture, Kyushu University

他

https://doi.org/10.5109/4363557

出版情報：九州大学大学院農学研究院紀要. 66 (1)，pp.97-104，2021-03-01. Faculty of Agriculture， Kyushu University

バージョン :

権利関係 : 


\title{
Eutrophication Status of Lakes in Inner Hanoi and a Case Study of Cu Chinh Lake
}

\author{
Ta Dang THUAN ${ }^{1}$, Bui Quoc LAP ${ }^{2 *}$, Le Minh THANH, Masayoshi HARADA ${ }^{3}$, \\ Kazuaki HIRAMATSU ${ }^{3}$ and Toshinori TABATA ${ }^{3}$
}

\author{
Laboratory of Water Environment Engineering, Division of Bioproduction Environmental Sciences, \\ Department of Agro-environmental Sciences \\ (Received October 7, 2020 and accepted November 4, 2020)
}

\begin{abstract}
Many lakes in inner Hanoi have been affected by eutrophication, which commonly leads to uncontrolled growth of algae, generation of cyanobacteria and toxic algae, increased water-treatment costs, and lake shallowing. This study presents an overview of the recent eutrophication status in Hanoi lakes and compares the lakes with $\mathrm{Cu}$ Chinh Lake based on a case study performed from April 2017 to March 2018. The eutrophication was mainly assessed by comparing the nutritional parameters (phosphorus and nitrogen) with values of poor nutrition and the concentration of algal biomass with concentrations found in hypereutrophic lakes. In addition, we investigated which nutrients contribute to limiting the growth of algae based on the total nitrogen/total phosphorus ratio, and we identified groups of algae that contained typical species in $\mathrm{Cu}$ Chinh Lake. The nutrient levels and algal biomass in many lakes were maintained between the eutrophic and hypereutrophic limits and underwent seasonal changes throughout the year. In $\mathrm{Cu} \mathrm{Chinh}$ Lake, phosphorus is the predominant limiting nutrient for the development of algae. Thus, some typical algae genera, such as Microcystis, Anabaena of cyanobacteria, and Scenedesmus of green algae, are biological indicators of eutrophication in the lake.
\end{abstract}

Key words: Algae, Cyanobacteria, Eutrophication, Hanoi lakes, Nutritional Status Index

\section{INTRODUCTION}

Recently, the amount of pollutants in the lakes of Hanoi, including nutrients derived from domestic wastewater and urban runoff, has been increasing owing to the rapid economic development and urbanization of Hanoi. Hanoi has more than 100 large and small-sized lakes, which regulate rainwater, shape landscapes, harmonize the climate, and accommodate many water plants and animals. Most lakes in Hanoi are medium and smallsized, and relatively shallow. These lakes are facing many water quality problems, especially owing to eutrophication. Eutrophication leads to the uncontrolled growth of algae, including blue-green and toxic algae, which increases water-treatment costs and causes lake shallowing.

To overcome these problems, Hanoi has recently invested in wastewater-treatment projects that aim to control discharge sources, limit the direct discharge of wastewater into the lakes, and protect natural landscapes and surface water. The water quality in Hanoi lakes, especially in the inner-city areas, is being monitored more synchronously and regularly. However, the

${ }^{1}$ Division of Environmental Engineering Technology, Faculty of Chemical and Environmental Technology, Hung Yen University of Technology and Education, Vietnam

${ }^{2}$ Division of Environmental Management, Faculty of Chemistry and Environment, Thuyloi University, 175 Tay Son, Dong Da, Hanoi, Vietnam

* Corresponding author (E-mail: buiquoclap@tlu.edu.vn)

Laboratory of Water Environment Engineering, Division of Bioproduction Environmental Sciences, Department of Agroenvironmental Sciences, Faculty of Agriculture, Kyushu University monitoring and analysis of the water quality mainly focus on comparing and evaluating various parameters with the national standards for specific uses of surface water. Most assessments of the eutrophication status of the lakes follow qualitative methods and avoid the quantitative evaluation of parameters that are closely related to eutrophication. However, recent studies on the eutrophication process have performed quantitative evaluations and followed the methods of Hakanson and Carlson (Nguyen et al., 2016; Nguyen et al., 2017; Pham et al., 2018).

\section{MATERIALS AND METHODS}

\section{Study area}

In this research, we evaluated the eutrophication status of ten typical lakes in inner Hanoi and investigated a case study on $\mathrm{Cu}$ Chinh Lake. Hanoi is the capital city of Vietnam, and it is located in northern Vietnam. It covers an area of $3328.9 \mathrm{~km}^{2}$ with an estimated population of 8.1 million (2019). Hanoi is the second largest city in Vietnam after Ho Chi Minh City, which is located in southern Vietnam. According to a report on Hanoi lakes (Nguyen, 2015), inner Hanoi has 112 ponds with a total water surface area of $6959305 \mathrm{~m}^{2}$; this area decreased by $72540 \mathrm{~m}^{2}$ since 2010 owing to urbanization. Among over 100 lakes in inner Hanoi, we selected ten typical lakes to overview their eutrophication state and $\mathrm{Cu}$ Chinh Lake for a more detailed investigation. The locations of all studied lakes are shown in Fig. 1.

Many lakes in Hanoi have partially or permanently disappeared owing to the urbanization. The lakes in inner Hanoi are mainly shallow with depths of 1.5-4.0 m (Nguyen, 2015); thermal stratification occurs in the 

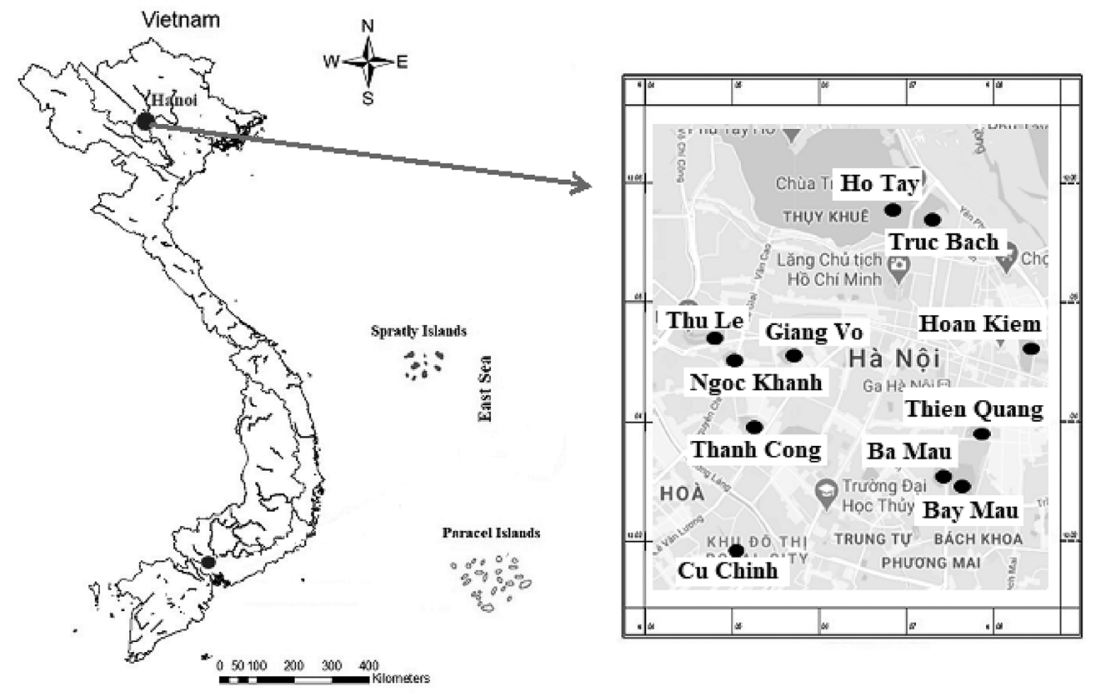

\begin{tabular}{|c|c|c|c|c|c|}
\hline No. & Lake name & Location & No. & Lake name & Location \\
\hline 1 & Thu Le & $21^{\circ} 01^{\prime} 50.0^{\prime \prime} \mathrm{N} ; 105^{\circ} 48^{\prime} 32.4^{\prime \prime E}$ & 7 & Thien Quang & $21^{\circ} 01^{\prime} 04.9^{\prime \prime} \mathrm{N} 105^{\circ} 50^{\prime} 45.1^{\prime \prime E}$ \\
\hline 2 & Thanh Cong & $21^{\circ} 01^{\prime} 08.8^{\prime \prime N} 105^{\circ} 48^{\prime} 50.9^{\prime \prime E}$ & 8 & Truc Bach & $21^{\circ} 02^{\prime} 46.1^{\prime \prime} \mathrm{N} 105^{\circ} 50^{\prime} 17.7^{\prime \prime E}$ \\
\hline 3 & Ba Mau & $21^{\circ} 00^{\prime} 44.4^{\prime \prime} \mathrm{N} 105^{\circ} 50^{\prime} 24.3^{\prime \prime E}$ & 9 & Ngoc Khanh & $21^{\circ} 01^{\prime} 38.9^{\prime \prime N} 105^{\circ} 48^{\prime} 39.8^{\prime \prime E}$ \\
\hline 4 & Bay Mau & $21^{\circ} 00^{\prime} 42.7^{\prime \prime} \mathrm{N} 105^{\circ} 50^{\prime} 36.1 " \mathrm{E}$ & 10 & Giang Vo & $21^{\circ} 01^{\prime} 40.7 " \mathrm{~N} 105^{\circ} 49^{\prime} 10.3 " \mathrm{E}$ \\
\hline 5 & West Lake & $21^{\circ} 02^{\prime} 56.0^{\prime \prime} \mathrm{N} 105^{\circ} 49^{\prime} 53.0^{\circ} \mathrm{E}$ & 11 & Cu Chinh & $21^{\circ} 00^{\prime} 00.0^{\prime \prime} \mathrm{N} 105^{\circ} 48^{\prime} 00.0^{\prime \prime E}$ \\
\hline 6 & Hoan Kiem & $21^{\circ} 01^{\prime} 50.2^{\prime \prime} \mathrm{N} 105^{\circ} 51^{\prime} 08.6 " \mathrm{E}$ & & & \\
\hline
\end{tabular}

Fig. 1. Map of the study area.

water column but the level is not significant, especially in shallow lakes. Thus, these lakes retain uniformity in temperature, which ensures the well-mixing of nutrients.

Along with the rapid economic development and urbanization of Hanoi, the amount of pollutants and nutrients derived from domestic wastewaters and urban runoffs has increased.

$\mathrm{Cu}$ Chinh Lake is a shallow urban lake located in the inner city with a geographic position of $21^{\circ} 00^{\prime}$ North latitude, $105^{\circ} 48^{\prime}$ East longitude, in the southwest of downtown Hanoi (Fig. 2).

$\mathrm{Cu}$ Chinh Lake borders Thuong Dinh and Nhan Chinh Ward (Thanh Xuan District). The lake is sur-

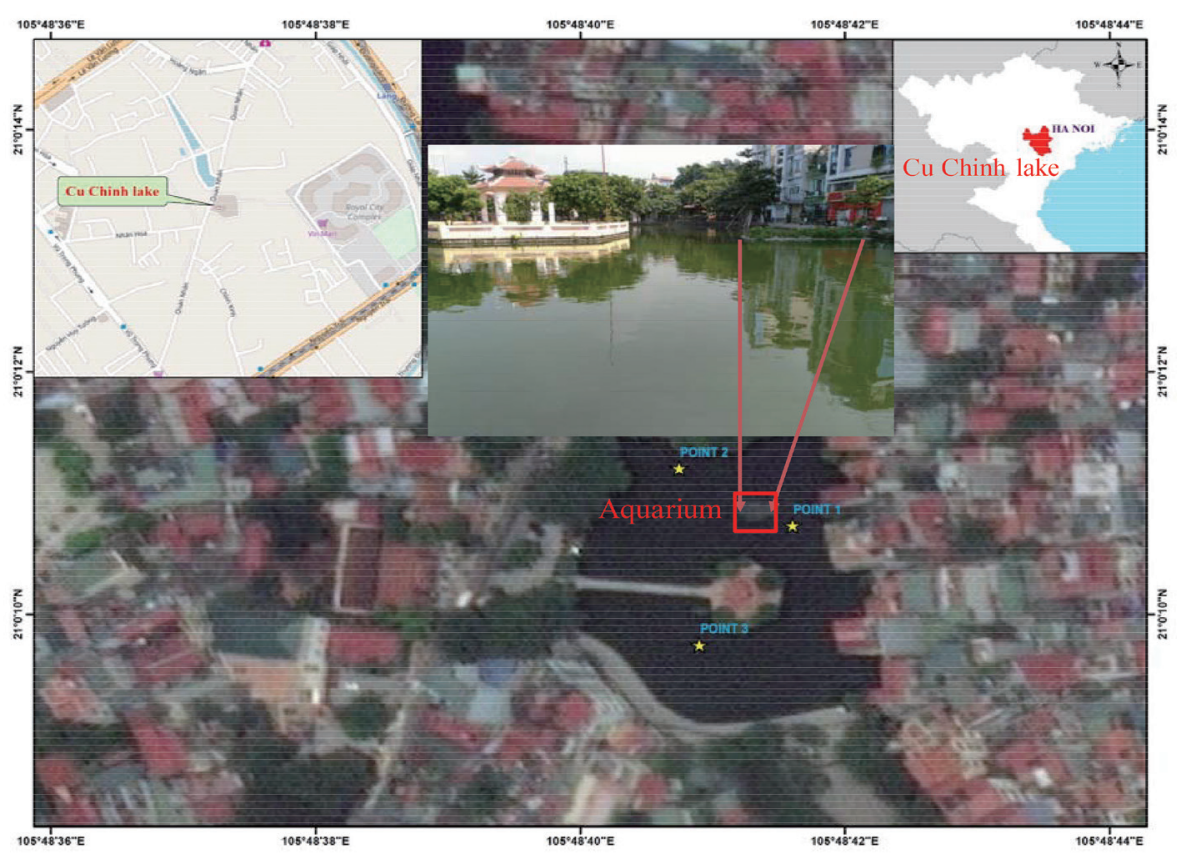

Fig. 2. Location of $\mathrm{Cu}$ Chinh Lake. 
rounded by a densely populated commercial area. This area includes residential housing, land for commercial areas, offices, schools and hospitals, and roads (e.g., Quan Nhan Street, which has high traffic density). There was almost no direct discharge into $\mathrm{Cu}$ Chinh Lake because the domestic wastewater and runoff were largely collected into the city's sewage system. The discharge of groundwater into $\mathrm{Cu}$ Chinh Lake was also very limited because the surrounding embankments were made of bricks and reinforced concrete. Rainfall and rainwater flows were the only water bodies that were directly discharged into $\mathrm{Cu}$ Chinh Lake.

The circumference of the lake is approximately $250 \mathrm{~m}$, and the water surface area is approximately $4000 \mathrm{~m}^{2}$. The largest length is approximately $75 \mathrm{~m}$, the largest width is approximately $65 \mathrm{~m}$, the average depth is in the range of $1.5-1.7 \mathrm{~m}$, and the average water capacity is approximately $4600 \mathrm{~m}^{3}$. $\mathrm{Cu}$ Chinh Lake harmonizes the microclimate and regulates the rainwater, while it is also a place of entertainment for people in the surrounding area. The campus around the lake had a concrete surface, an area of approximately $1500 \mathrm{~m}^{2}$, and it was used for parking lots and gyms. Although small, the lake could mix nutrients better than larger lakes.

\section{Water sampling}

Water and phytoplankton samples were collected from the study area between April 2017 and March 2018. The sampling occurred one to two times per month from 9:00 am to 10:00 am. Representative samples were attained by mixing samples from three points, $20 \mathrm{~cm}$ below the water surface (Fig. 2). In total, 16 representative samples were collected.

Water samples were attained in accordance with the Vietnam standard 5994-1995 (ISO 5667-4: 1987) for sampling in natural and artificial ponds, and they were immediately filtered through a GF/F filter paper (Whitman). The filtered samples were stored separately in plastic bottles (PE) until the analysis of the nutrient concentrations. Unfiltered water samples were used for total phosphorus (TP) analysis. The samples without immediate analysis were refrigerated at $0-4^{\circ} \mathrm{C}$. Finally, a certain volume of water was collected and fixed by a Lugol solution to determine the density of the floating plant cells (Duong et al., 2012).

\section{Methods of analysis}

The parameters $\mathrm{NH}_{4}-\mathrm{N}, \mathrm{NO}_{3}-\mathrm{N}, \mathrm{NO}_{2}-\mathrm{N}, \mathrm{PO}_{4}-\mathrm{P}, \mathrm{TP}$, total nitrogen (TN), and chlorophyll a (Chl a) were determined via the colorimetric method using a DR 2800 spectrophotometer (Hach, USA) and a UV-V630 spectrophotometer in accordance with the APHA methods (APHA, 2001). The total organic carbon (TOC) and dissolved organic carbon (DOC) were analyzed using a TOC-V E Total Organic Carbon Analyzer (Shimadzu, Japan). The number of cells was counted on the Sedgewick Rafter counting chamber under a reverse microscope. The species composition was determined using an Olympus BX51 microscope (Duong et al., 2012).

\section{Eutrophication evaluation}

In this research, the following methods were used:

1) The ratio of TN/TP was compared with the standards of the World Health Organization (WHO) to determine which nutrients were the limiting factors for the growth of algae. According to the WHO standards, phosphorus is a limiting nutrient when the ratio of TN/TP is greater than 6 , whereas nitrogen is a limiting nutrient when the ratio is less than 4.5. When the TN/TP ratio ranges between 4.5 and 6 , phosphorus, nitrogen, or both can be limiting nutrients (WHO, 2002).

2) Carlson's trophic status indices (TSI), viz. TSI (TP), TSI (Chl a) (Schindler, 1977), and TSI (TN) (Kratzer et $a l ., 1981)$ were calculated based on the formulas:

$$
\begin{aligned}
& \text { TSI }(\mathrm{TP})=14.42 \times \ln (\mathrm{TP})+4.15 \\
& \text { TSI }(\mathrm{Chl} \mathrm{a})=9.81 \times \ln (\mathrm{Chl} \mathrm{a})+30.6 \\
& \text { TSI }(\mathrm{TN})=14.43 \times \ln (\mathrm{TN})+54.45
\end{aligned}
$$

The eutrophication state of the lake was assessed in accordance with the Carlson and Simpson standards (Carlson et al., 1996), in which Carlson's TSI is the average value of TSI (TN), TSI (TP), and TSI (Chl a). The lake is classified as oligotrophic when TSI $<40$ (I), mesotrophic when $40 \leq$ TSI $\leq 50$ (II), eutrophic when $50<$ TSI $\leq 70$ (III), and hypertrophic when TSI $>70$ (IV).

3) The values of the TP, TN, and Chl a parameters were correlated with the classification of nutrients in accordance with the Hakanson standards (Hakanson et al., 2007).

\section{RESULTS AND DISCUSSION}

\section{Overview of the previous studies}

Nguyen et al. (2017) (Table 1) showed that ten monitored lakes in inner Hanoi (Fig. 1) were highly polluted with nutrients. Specifically, Ba Mau Lake had the highest level of nutrients, followed by Giang Vo, Ngoc Khanh, Truc Bach, Thanh Cong, Ho Tay, Thien Quang, Bay Mau, Hoan Kiem, and Thu Le. The concentrations of parameters such as TN (1.29-4.63 mg/l) and TP $(0.23-1.69 \mathrm{mg} / \mathrm{l})$ in all ten lakes were classified via the Hakason method as the fourth level (IV) of nutrient pollution (hypertrophic). Although all lakes were hypertrophic with respect to TN and TP, most were from oligotrophic to mesotrophic with respect to $\mathrm{Chl}$ a, except for Giang Vo Lake which was eutrophic. This suggested that these nutrient-polluted lakes did not have favorable conditions for algae growth. However, this should be studied in more detail. In addition, there was a seasonal variation; i.e., the concentration of nutrients in the dry season was higher than that in the rainy season (Nguyen et al., 2017). Carlson's TSI ranged from 56.8 (Thu Le Lake) to 78.1 (Ba Mau Lake). Based on the standards of the US Environmental Protection Agency, the nutritional status in these lakes ranged from eutrophic to hypertrophic, and it followed the order: Ba Mau > Giang Vo > Ngoc Khanh $>$ Truc Bach $>$ Thanh Cong $>$ Ho Tay $>$ Thien Quang > Bay Mau > Hoan Kiem > Thu Le (Nguyen et al., 2017). This revealed that the three lakes 
Table 1. Eutrophication levels of ten monitored lakes in Hanoi

\begin{tabular}{|c|c|c|c|c|c|c|c|c|c|c|}
\hline Parameter Lake & $\mathrm{Ba} \mathrm{Mau}$ & $\begin{array}{l}\text { Giang } \\
\text { Vo }\end{array}$ & $\begin{array}{l}\text { Ngoc } \\
\text { Khanh }\end{array}$ & $\begin{array}{l}\text { Truc } \\
\text { Bach }\end{array}$ & $\begin{array}{l}\text { Thanh } \\
\text { Cong }\end{array}$ & Ho Tay & $\begin{array}{l}\text { Thien } \\
\text { Quang }\end{array}$ & $\begin{array}{l}\text { Bay } \\
\text { Mau }\end{array}$ & $\begin{array}{l}\text { Hoan } \\
\text { Kiem }\end{array}$ & Thu Le \\
\hline Area (ha) & 4.6 & 6 & 3.5 & 22 & 6.5 & 446 & 5.5 & 21.3 & 12 & 9.9 \\
\hline Depth (m) & $2.5-3.0$ & $2.5-3.0$ & 2.5 & $1.5-2.0$ & $3.0-4.0$ & $2.0-4.0$ & $3.0-4.0$ & $2.0-2.5$ & $1.5-2.0$ & $2.0-3.0$ \\
\hline $\mathrm{TN}(m g / l)$ & $\begin{array}{l}4.63 \\
\text { (IV) }\end{array}$ & $\begin{array}{l}3.22 \\
\text { (IV) }\end{array}$ & $\begin{array}{l}3.12 \\
\text { (IV) }\end{array}$ & $\begin{array}{l}2.72 \\
\text { (IV) }\end{array}$ & $\begin{array}{l}2.20 \\
\text { (IV) }\end{array}$ & $\begin{array}{l}1.72 \\
\text { (IV) }\end{array}$ & $\begin{array}{l}2.47 \\
\text { (IV) }\end{array}$ & $\begin{array}{l}2.23 \\
\text { (IV) }\end{array}$ & $\begin{array}{l}0.82 \\
\text { (IV) }\end{array}$ & $\begin{array}{l}1.29 \\
\text { (IV) }\end{array}$ \\
\hline $\mathrm{TP}(m g / l)$ & $\begin{array}{l}1.69 \\
(\mathrm{IV})\end{array}$ & $\begin{array}{l}1.27 \\
(\mathrm{IV})\end{array}$ & $\begin{array}{l}1.77 \\
\text { (IV) }\end{array}$ & $\begin{array}{l}0.55 \\
\text { (IV) }\end{array}$ & $\begin{array}{l}0.4 \\
\text { (IV) }\end{array}$ & $\begin{array}{l}0.41 \\
\text { (IV) }\end{array}$ & $\begin{array}{l}0.41 \\
(\mathrm{IV})\end{array}$ & $\begin{array}{l}0.28 \\
(\mathrm{IV})\end{array}$ & $\begin{array}{l}0.26 \\
(\mathrm{IV})\end{array}$ & $\begin{array}{l}0.23 \\
(\mathrm{IV})\end{array}$ \\
\hline Chl.a $(\mu g / l)$ & $\begin{array}{l}5.0 \\
(\mathrm{I})\end{array}$ & $\begin{array}{l}7.7 \\
\text { (III) }\end{array}$ & $\begin{array}{l}4.2 \\
\text { (II) }\end{array}$ & $\begin{array}{l}3.1 \\
\text { (II) }\end{array}$ & $\begin{array}{l}2.4 \\
\text { (II) }\end{array}$ & $\begin{array}{l}3.1 \\
\text { (II) }\end{array}$ & $\begin{array}{l}1.4 \\
\text { (I) }\end{array}$ & $\begin{array}{l}1.3 \\
(\mathrm{I})\end{array}$ & $\begin{array}{l}5.3 \\
\text { (II) }\end{array}$ & $\begin{array}{l}0.9 \\
\text { (I) }\end{array}$ \\
\hline Carlson-TSI & 78.1 & 76.4 & 75.9 & 68.5 & 65.2 & 65.0 & 64.1 & 61.6 & 61.0 & 56.8 \\
\hline Overall classification $^{(*)}$ & $\mathrm{HT}$ & $\mathrm{HT}$ & $\mathrm{HT}$ & $\mathrm{ET}$ & $\mathrm{ET}$ & $\mathrm{ET}$ & $\mathrm{ET}$ & $\mathrm{ET}$ & $\mathrm{ET}$ & $\mathrm{ET}$ \\
\hline
\end{tabular}

(*) HT - Hypertrophic; ET - Eutrophic

with the smallest water surface areas (Ba Mau, Giang Vo, and Ngoc Khanh) were the most nutrient-polluted (hypertrophic), whereas the remaining lakes with larger water surface areas tended to be less nutrient-polluted (only eutrophic). This observation can be explained by the fact that lakes with larger water surface areas can dilute nutrients better and decrease their concentrations. More importantly, a larger water surface area implies a larger air-water interface, which means that wind acts on the water surface more effectively and improves the circulation (wind-induced circulation). As a result, the pollutants and nutrients were circulated and mixed better, which favored the decomposition and absorption of nutrients by aquatic plants. This explains why lakes with large water surface areas tended to be less eutrophic than those with smaller water surface areas.

Nguyen et al. (2017) researched six lakes in inner Hanoi, viz. Ba Mau, Bay Mau, Truc Bach, Hai Ba Trung, Hoan Kiem, and Dam Tri. Their results showed that most lakes were highly polluted with $\mathrm{NH}_{4}-\mathrm{N}$ and $\mathrm{PO}_{4}-\mathrm{P}$, whose concentrations were two to three times higher than the allowable standards of QCVN 08MT: 2015/ BTNMT, column A2 (water quality standard for the conservation of aquatic life). The TSI of these lakes ranged from 59.1 to 88.6, indicating that the lakes ranged from eutrophic to hypertrophic Additionally, the lakes had a higher eutrophication level in the dry season. Furthermore, research on Truc Bach, Thu Le, and Linh Dam (Pham et al., 2018) showed that the TP and TN concentrations were considered suitable parameters to monitor the eutrophication status of the lakes. The values of TSI (TP) and TSI (TN) of these lakes were greater than 70, which suggested that the nutritional status in the lakes during the monitoring period was maintained at the hypertrophic level.

In addition, eutrophication promoted the growth and development of algae groups in the lakes. Le (2009) studied ten lakes in Hanoi and reported that there were five main groups of algae, viz. green algae, silica algae, ophthalmic algae (Euglenophyta), two-channel algae (Dinophyta), and a group of cyanobacteria; the groups with the predominant density were green algae ( 51 spe- cies) and cyanobacteria (22 species).

Duong et al. (2012) reported that the composition of phytoplankton in Hoan Kiem Lake was dominated by cyanobacteria (accounting for 90\% of the total phytoplankton). Many cyanobacteria species had the ability to produce toxins, such as species of the Microcystis genus, which form a thick scum on the surface of the water during the blooming season and produce hepatotoxins (microcystins). The concentrations of these toxins ranged from $2.1-46 \mu \mathrm{g}$ microcystins/l with an average density of $386.94 \times 10^{6}$ cells/ml. In addition, West Lake exhibited diverse communities of silica algae with six main families of algae, mainly species with a wide distribution of representative tropical and subtropical species, such as Nitzschia palea, Gomphonema parvulum, Cyclotella meneghiniana, and Aulacoseira granulata (Duong et al., 2012).

The results of the previous studies showed that many lakes in inner Hanoi remained eutrophic. The nutrient levels of most lakes were maintained from eutrophic to hypertrophic during the study period. Green algae and cyanobacteria constituted a large proportion of the algae. The Microcystis genus of cyanobacteria produces liver toxins that adversely affect the health of animals in the lakes.

Thus, the above studies focused only on the eutrophication assessment through individual aspects, such as the concentration of nutrients, groups of algae, and algae genera appearing in the lakes. Those studies have not shown the effect of nutrients and environmental factors such as water temperature or solar radiation intensity on the growth and development of algae groups, which is typically expressed by the concentration of algae biomass and cell density of algae groups.

In addition, the above studies focused on shallow lakes located in inner Hanoi and most received both point and non-point wastewater sources. However, there are some lakes with well-controlled urban sewage systems that do not experience direct discharge of domestic wastewater, such as Hoan Kiem, Thien Quang, and Thu Le Lakes. Nevertheless, eutrophication proceeded in these lakes as well, suggesting that the eutrophication is not only due to the wastewater dis- 
charged directly into the lakes but also due to nutrients added from the atmosphere, runoffs into the lakes, waste excreted by lake plants and animals, and the dispersion of nutrients from lake sediments.

\section{Eutrophication of Cu Chinh Lake} Assessment of the eutrophication level

Eutrophication index (TN/TP)

In addition to assessing the eutrophication level of $\mathrm{Cu}$ Chink Lake via the method of Hakanson and Carlson, the study considered which nutrients were limiting the growth of algae. The study also analyzed the cell densities of the algae groups that appeared in the lake and assessed their relationship to dissolved inorganic nutrient concentrations, water temperature, and solar radiation intensity.

Fig. 3 shows the TN/TP ratio of two seasons in the year. Fig. 4 shows the seasonal distribution of the TN/ $\mathrm{TP}$ ratio, which was used to determine the nutritional factor that limits the growth of algae. As shown in Fig. 3, the average value of the TN/TP ratio was 9.1, the highest value was 17.4 in May, and the lowest was 2.5 in June. Phosphorus was the main limiting nutrient, except during periods of heavy rainfall (from June to August) when nitrogen was the predominant limiting nutrient. This was explained by the fact that when the nutrient concentration in the lake was high, the temperature of the water was also high, while rainy days with few hours of sunshine led to low solar radiation intensity. This was unfavorable for algae growth; therefore, the concentration of TP increased sharply while the TN concentration was stable, resulting in a decrease in the TN/TP ratio.

Fig. 3 and 4 show that the range of the TN/TP ratio in the rainy season (from 2.5 to 17.4 ) was wider than that in the dry season (from 9.7 to 12.7). The lake's water quality should be monitored regularly to assess and manage the concentrations of limiting nutrients, thereby minimizing the risk of arising eutrophication.

The TSI of the lake was calculated for the monthly values of TSI (TP), TSI (TN), TSI (Chl a), as shown in Fig. 5. TSI (TN) was calculated for June, July, and August when nitrogen was a limiting nutrient. The average values of TSI (TP), TSI (TN), and TSI (Chl a) in $\mathrm{Cu}$ Chinh Lake were 77.2, 59.8, and 57.6, respectively. The values of TSI (TN) and TSI (Chl a) suggested that the lake was in the eutrophication state, whereas the value of TSI (TP) suggested that the lake was hypertrophic. Throughout the year, the lake's nutrition status remained eutrophic or even hypertrophic, which was expressed sharply in June and July when the temperature and nutrient concentration were high. The eutrophication status in $\mathrm{Cu}$ Chinh Lake was similar to those of the ten monitored lakes in inner Hanoi with a TSI ranging from 59.1 to 88.6 (Nguyen et al., 2017) and somewhat lower than those of the three lakes in Hanoi with TSI ranging from 75.6 to 87.63 in the research of Pham et al. (2018).

Table 2 shows a comparison between the annual average and seasonal values of the concentrations of TN, $\mathrm{TP}$, and Chl a (the rainy season was from May to September and the dry season was from October to April

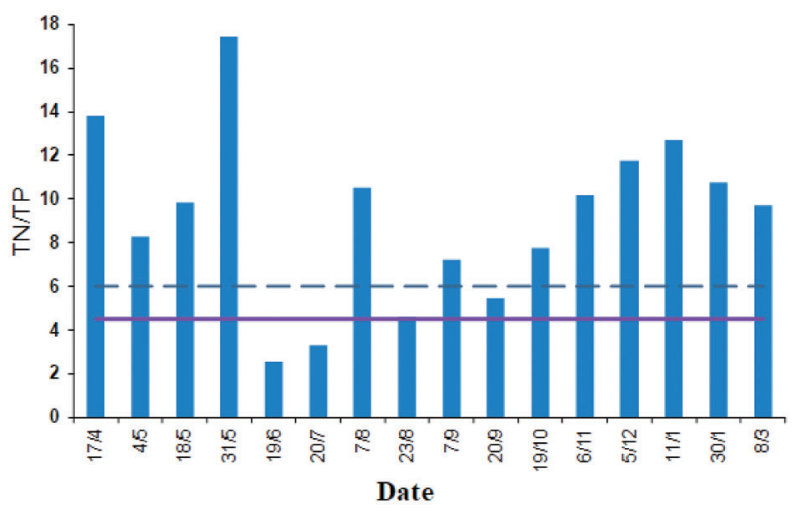

Fig. 3. TN/TP ratios with respect to different observation times.

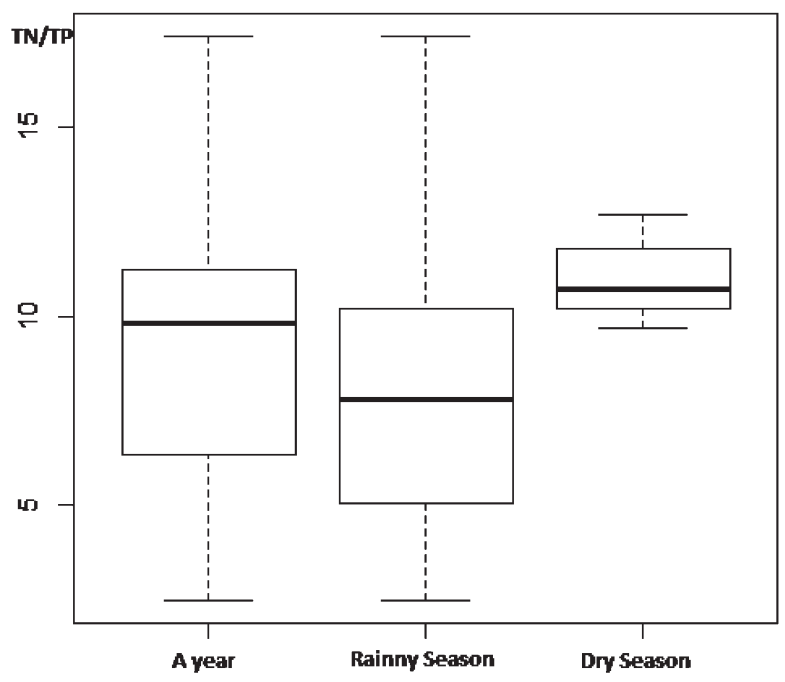

Fig. 4. Seasonal TN/TP ratios of $\mathrm{Cu}$ Chinh Lake.

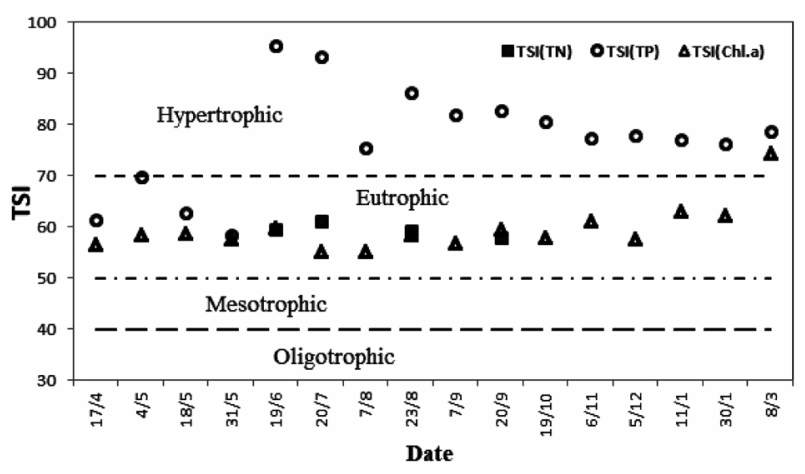

Fig. 5. Lake eutrophication state based on Carlson's trophic status index.

of next year) with the nutrient classification of the lake based on the method by Hakanson et al. (2007).

As shown in Table 2, the concentrations of TN and $\mathrm{TP}$ indicated that the lake was always hypertrophic in both rainy and dry seasons. This result was similar to those of the ten studied lakes, although the average values of TN and TP in Cu Chinh Lake were slightly lower than those of the ten lakes. The annual and seasonal values of Chl a were significantly greater than those of the 
Table 2. Classification of nutrition in Cu Chinh Lake via Hakanson and Carlson's trophic status index methods

\begin{tabular}{|c|c|c|c|c|c|c|c|}
\hline \multirow{2}{*}{$\begin{array}{l}\text { Classify } \\
\text { Parameter }\end{array}$} & \multirow{2}{*}{ Oligotrophic } & \multirow{2}{*}{ Mesotrophic } & \multirow{2}{*}{ Eutrophic } & \multirow{2}{*}{ Hypertrophic } & \multicolumn{3}{|c|}{ Cu Chinh Lake } \\
\hline & & & & & Average year & Rainy season & Dry season \\
\hline $\begin{array}{c}\mathrm{TP} \\
(\mathrm{mg} / \mathrm{L})\end{array}$ & $<0.008$ & $0.008-0.025$ & $0.025-0.06$ & $>0.06$ & $\begin{array}{c}0.2 \\
\text { (Hypertrophic) }\end{array}$ & $\begin{array}{c}0.218 \\
\text { (Hypertrophic) }\end{array}$ & $\begin{array}{c}0.162 \\
\text { (Hypertrophic) }\end{array}$ \\
\hline $\begin{array}{c}\mathrm{TN} \\
(\mathrm{mg} / \mathrm{L})\end{array}$ & $<0.06$ & $0.06-0.18$ & $0.18-0.43$ & $>0.43$ & $\begin{array}{c}1.378 \\
\text { (Hypertrophic) }\end{array}$ & $\begin{array}{c}1.12 \\
\text { (Hypertrophic) }\end{array}$ & $\begin{array}{c}1.78 \\
\text { (Hypertrophic) }\end{array}$ \\
\hline $\begin{array}{c}\text { Chl.a } \\
(\mu \mathrm{g} / \mathrm{L})\end{array}$ & $<2$ & $2-6$ & $6-20$ & $>20$ & $\begin{array}{c}17.72 \\
\text { (Eutrophic) }\end{array}$ & $\begin{array}{c}15.5 \\
\text { (Eutrophic) }\end{array}$ & $\begin{array}{c}22.28 \\
\text { (Hypertrophic) }\end{array}$ \\
\hline $\begin{array}{l}\text { Carlson- } \\
\text { TSI }\end{array}$ & $<40$ & $40-50$ & $50-70$ & $>70$ & $\begin{array}{c}67.2 \\
\text { (Eutrophic) }\end{array}$ & $\begin{array}{c}65.3 \\
\text { (Eutrophic) }\end{array}$ & $\begin{array}{c}70.4 \\
\text { (Hypertrophic) }\end{array}$ \\
\hline
\end{tabular}

ten lakes, $(17.72 \mu \mathrm{g} / \mathrm{l}, 15.5 \mu \mathrm{g} / \mathrm{l}$ in the rainy season, $22.28 \mu \mathrm{g} / \mathrm{l}$ in the dry season) and the lake was eutrophic to hypertrophic, whereas the ten lakes were oligotrophic to mesotrophic. The concentration of $\mathrm{Chl}$ a in $\mathrm{Cu}$ Chinh Lake during the rainy season was the lowest, which could be explained by the fact that the environmental factors in this period (water temperature and solar radiation intensity) did not favor algae growth.

In general, the indices used to assess the eutrophication level in the lake via different methods were highly consistent. Most indices indicated that $\mathrm{Cu}$ Chinh Lake was eutrophic and hypertrophic throughout the year (although the concentration of nutrients varied). The growth of algae was mainly limited by phosphorus; nitrogen was a limiting nutrient for a short period during the rainy season.

\section{Phytoplankton community}

In this study, the phytoplankton community (mainly algae) in $\mathrm{Cu}$ Chinh Lake included five groups of algae: Cyanobacteria, Chlorophyta (green algae), Bacillariophyta (silica algae), Euglenophyta (ophthalmic algae), and Dinophyta (two-channel algae). The typical genera of the algae groups are presented in Table 3, the percentage of algae groups is shown in Fig. 6, the cell density of the algae groups is shown in Fig. 7, and the cell density of cyanobacteria and green algae are shown in Fig. 8 and 9 .

Table 3 shows that the composition of algae groups in $\mathrm{Cu}$ Chinh Lake is commonly found in freshwater ecosystems and some typical algae genera were biological indicators of eutrophication in lakes, such as Microcystis, Anabaena of cyanobacteria, and the Scenedesmus genus of green algae (Tran, 2011).

Fig. 6 shows that the green algae group had the largest average cell density of $50.2 \%$ between all phytoplankton present in $\mathrm{Cu}$ Chinh Lake (the highest was 67.7\% in October and the lowest was 37.2\% in August). The second largest group was cyanobacteria with an average cell density of $46.55 \%$ (the highest was $58.41 \%$ in August and the lowest was 29\% in October). Conversely, two-channel, ophthalmic, and silica algae exhibited cell densities of less than 0.32-2.53\%.

The cell density of algae in $\mathrm{Cu}$ Chinh Lake ranged from $4.9 \times 10^{7}$ to $18.6 \times 10^{7}$ cells/l with an average value of $8.87 \times 10^{7}$ cells/l. The highest value was recorded on
December 5, 2017, and the lowest on July 20, 2017. Green algae and cyanobacteria were the two groups of algae with the dominant density and relatively stable growth during the monitoring period.

The genus Microcystis of the cyanobacteria group produces hepatotoxins such as microcystins, and the genus Anabaena produces neurotoxins, saxitoxins (which commonly cause paralytic shellfish poisoning), anatoxin-a, guanitoxin and homoanatoxin-a (Tran, 2011). Fig. 7 shows that the genus Microcystis of the cyanobacteria group was dominant with a cell density ranging from $1.97 \times 10^{7}$ cells $/ 1$ to $9.18 \times 10^{7}$ cells $/ 1$ (accounting for $28.6-75.5 \%$ of the total cell density). This genus appeared in all the samples, with an especially high density during the rainy months. The presence of this genus indicates a high risk of poisoning for aquatic animals and plants in the lake.

The fluctuations in cell density of green algae in $\mathrm{Cu}$ Chinh Lake are shown in Fig. 8. The lowest density was $1.87 \times 10^{7}$ cells/l recorded on July 20,2017 , and the highest was $9.15 \times 10^{7}$ cells/l on December 5, 2017. Among the groups of green algae, Scenedesmus and Pediastrum had cell densities accounting for over 91\% during the monitoring period. Although Pediastrum adapted to clean water conditions, Scenedesmus favored a more nutrient-rich environment.

With an average cell density of up to $80.9 \%$ of the total cell density, Scenedesmus was predominant during the observation period (always greater than 70\%). This indicated that the water in the lake was contaminated with nutrients.

The relationships between the cell densities of algal groups and exogenous variables, such as nutrient concentrations (easily absorbed by algae), dissolved inorganic nitrogen (DIN) and dissolved inorganic phosphorus (DIP), dissolved oxygen concentration, water temperature, and solar radiation intensity were assessed based on the Spearman correlation coefficient and are shown in Fig. 9, 10, and 11.

Fig. 9 shows that $\mathrm{Cu}$ Chinh Lake had a higher average cell density of algae during the dry season (from November 2017 to March 2018) than during the rainy season. The algae cell density values increased dramatically in December 2017 and March 2018. Moreover, the concentration of nutrients that are easily absorbed by algae (DIN + DIP) was always maintained at a high 


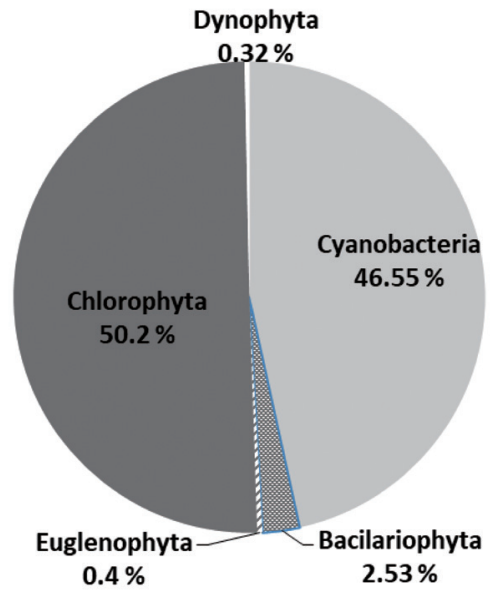

Fig. 6. Percentage of algae groups in $\mathrm{Cu}$ Chinh Lake.

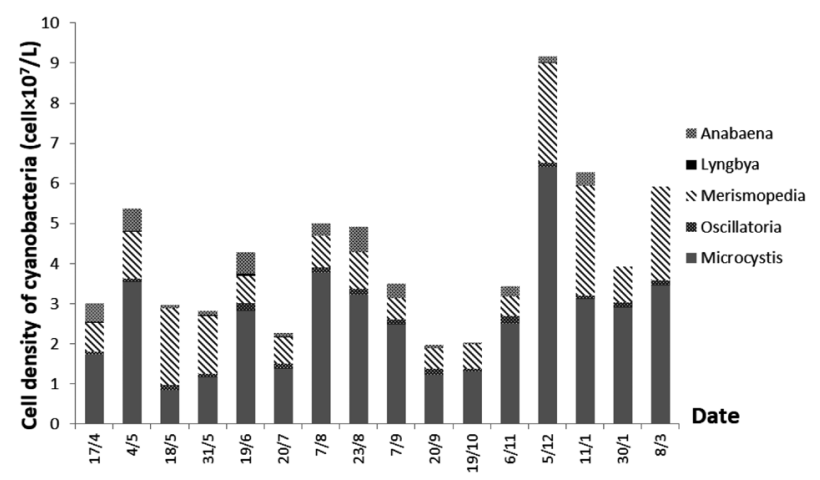

Fig. 7. Changes in cell density of cyanobacteria in $\mathrm{Cu}$ Chinh Lake.

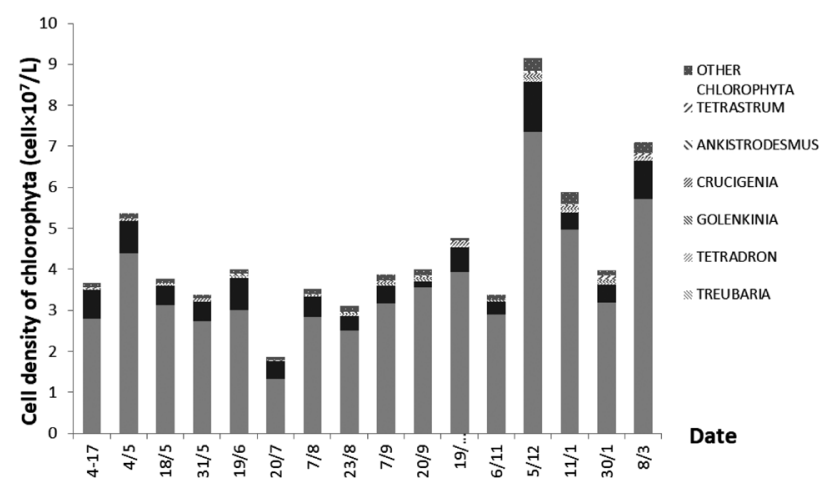

Fig. 8. Fluctuations in cell density of green algae in $\mathrm{Cu}$ Chinh Lake.

Table 3. Algae group and typical algae genera

\begin{tabular}{cc}
\hline Algae group & Typical algae genera \\
\hline Cyanobacteria & Microcystis, Merismopedia, Anabaena \\
Chlorophyta & Scenedesmus,Pediastrum \\
Bacilariophyta & Cyclotella \\
Euglenophyta & Euglena \\
Dinophyta & Glenodinium \\
\hline
\end{tabular}

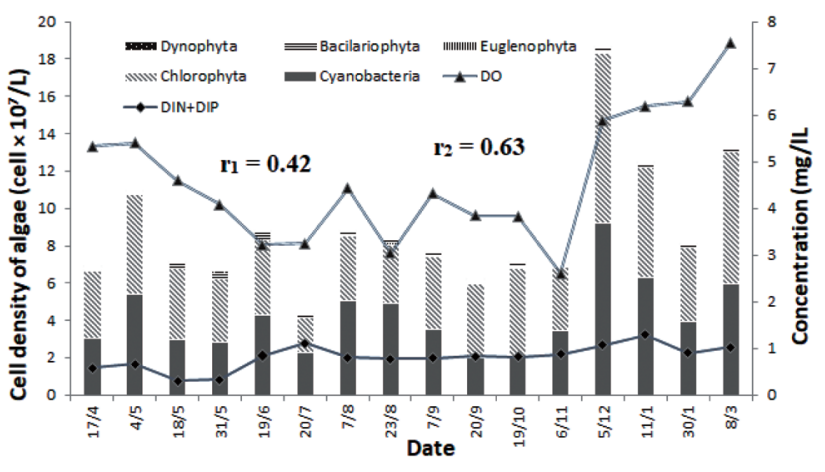

Fig. 9. Relationship between dissolved inorganic nitrogen \& dissolved inorganic phosphorus, dissolved oxygen concentration, and cell density.

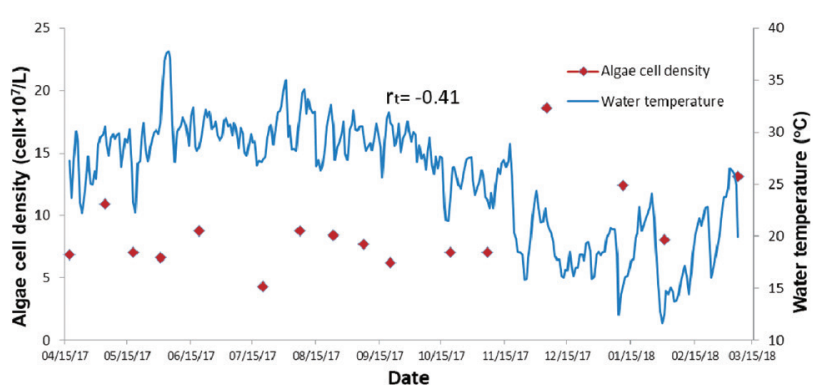

Fig. 10. Relationship between water temperature and algal cell density.

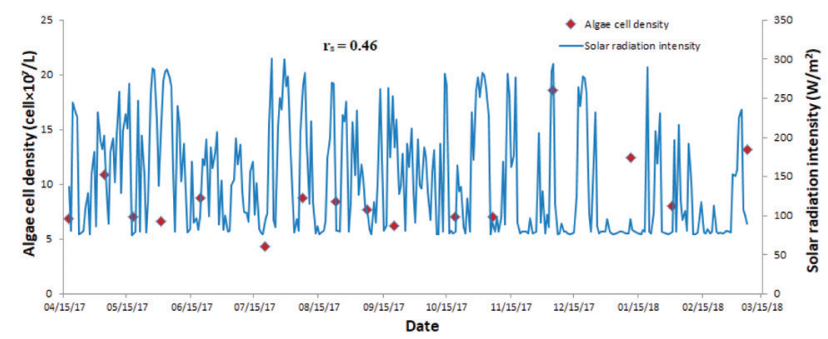

Fig. 11. Relationship between solar radiation intensity and algal cell density.

threshold, and the water temperature and solar radiation intensity underwent strong fluctuations.

At times of high cell density, the water temperature ranged from $20.5^{\circ} \mathrm{C}$ to $29^{\circ} \mathrm{C}$ (Fig. 10) and the intensity of solar radiation (Fig. 11) remained at a high level; these were suitable conditions for the overgrowth of algae. For example, on December 5, 2017, the highest cell density was $18.6 \times 10^{7}$ cells $/$, the water temperature was $21.18^{\circ} \mathrm{C}$, and the solar radiation intensity was $300 \mathrm{~W} / \mathrm{m}^{2}$, which favored algae growth.

Conversely, when the cell density was low and the nutrient concentration in the lake was stable, one or both factors (water temperature and solar radiation intensity) would be unfavorable for the growth of algae. Fig. 11 shows that when the solar radiation intensity was low, the algae cell density remained below the average value. For example, on July 20, 2017, a nutrient concentration (DIN + DIP) of $1.14 \mathrm{mg} / \mathrm{l}$ and water temperature 
of $28^{\circ} \mathrm{C}$ were favorable conditions for algae growth. However, with one sunny hour per day and radiation intensity at a low value of $85 \mathrm{~W} / \mathrm{m}^{2}$, these conditions were not suitable for algae growth; therefore, the cell density of algae was low at approximately $4.9 \times$ $10^{7}$ cells/l. Moreover, high solar radiation intensity and water temperature $\left(\geq 30^{\circ} \mathrm{C}\right)$ inhibited the growth of algae. The cell density of algae was inversely correlated with water temperature $\left(r_{t}=-0.41\right)$, and positively correlated with nutrient concentrations $\left(r_{1}=0.42\right)$, solar radiation intensity $\left(r_{s}=0.46\right)$, and dissolved oxygen concentration $\left(\mathrm{r}_{2}=0.63\right)$. The latter correlation can be explained by the fact that, at the time of sampling, there was a high cell density of algae, which led to an increase in the dissolved oxygen concentration via photosynthesis.

\section{CONCLUSIONS}

The following conclusions were drawn from the above results:

1. Almost all lakes in inner Hanoi were between eutrophic and hypertrophic because they received domestic wastewaters and urban runoffs from their surrounding areas without exchanging with external waters. Therefore, it is necessary to apply effective measures for improving the water quality of these lakes.

2. Although almost all lakes were from eutrophic to hypertrophic with respect to TN and TP, most lakes were from oligotrophic to mesotrophic with respect to Chl a. This suggested that the lakes did not favor algae growth. 3. The lakes with the smallest water surface areas tended to be more eutrophic than those with larger water surface areas. This was because the latter can circulate better by wind-induced currents and promote the decomposition and absorption of nutrients by aquatic plants, in addition to the improved diluting capability due to their larger water volume.

4. Cu Chinh Lake was heavily polluted with organic substances and nutrients. The eutrophication level of the lake ranged from eutrophic to hypertrophic. Phosphorus was the main limiting nutrient, except for a short period in the rainy season (June to August) when nitrogen was a limiting nutrient for the growth of algae. Thus, to control the eutrophication state in $\mathrm{Cu}$ Chinh Lake, it is necessary to focus on controlling phosphorus.

5. The composition of phytoplankton in $\mathrm{Cu}$ Chinh Lake was dominated by green algae and cyanobacteria, which included typical genera such as Scenedesmus (biological indicator for organic pollution), Microcystis, and Anabaena (blooms in water). The cell density of algae in the lake exhibited large fluctuations with a higher value during the rainy season. The fact that cyanobacteria, especially Microcystis and Anabaena, exhibited the highest density during the monitoring period indicated the risk of toxicity to plants and animals in the lake. Finally, the cell density of algae had a close relationship with the nutrient concentration and environmental factors such as water temperature and solar radiation intensity.

\section{AUTHOR CONTRIBUTIONS}

Ta Dang THUAN was resposible for sampling and analizing the water samples. Bui Quoc LAP designed the study, supervised the water sampling and analysis, prepared the manuscript and played the role of the corresponding author. Le Minh THANH supported to the water sampling and analysis as well as manuscript preparation. Masayoshi HARADA and Toshinori TABATA contributed to manuscript preparation, Kazuaki HIRAMATSU contributed to revise the manuscript.

\section{ACKNOWLEDGMENTS}

This research was funded by Hung Yen University of Technology and Education under the grand number UTEHY. L. 2020. 02.

\section{REFERENCES}

Carlson, R. J., and J. Simpson 1996 A coordinator's guide to volunteer lake monitoring methods, North American Lake Management Society

Duong, T. T and L. T. P. Quynh 2012 Diversity of silica algae in Ho Tay, Vietnam Journal of Science and Technology, $\mathbf{5 0}$ 361-66

Kratzer, C. and P. Brezonik 1981 A Carlson-type trophic state index for nitrogen in Florida lakes, Water Resources Bulletin, 174: $713-15$

Lars, H., A. C. Bryhn and J. K. Hytteborn 2007 On the issue of limiting nutrient and predictions of cyanobacteria in aquatic systems, Science of the Total Environment, 379: 89-108

Le, T. H 2009 The eutrophication and phytoplankton biodiversity of some lakes in Hanoi, Vietnam, in World Lake Conference in Wuhan, China, 339-45

Nguyen, B. T., N. T. B. Ngoc, D. T. Thuy, L. T. M. Hanh, P. Q. Long, L. D. Nghia and L. T. P. Quynh 2016 Preliminary investigations of organic pollution in water environment of some urban lakes in Hanoi city, Vietnam, J. Viet. Env., 8: 107-13

Nguyen, D. V., N. A. Bac and H. T. T. Huong 2016 Dissolved Oxygen as an Indicator for Eutrophication in Freshwater Lakes, In Proceedings of International Conference on Environmental Engineering and Management for Sustainable Development, 1-6

Nguyen, N. L 2015 Hanoi Lake Report 2015 (Women's Publishing House)

Nguyen, T. B. N, V. D. An, L. T. P. Quynh, N. B. Thuy, L. D. Nghia, D. T. Thuy and H. T. Cuong 2017 Evaluate the fertility level of some urban lakes in Hanoi, Vietnam Journal of Science and Technology, 55: 84-92

Nguyen, T. T. N 2017 Study on Trophic State in Lakes of Dong Da District, Hanoi, VNU Journal of Science: Earth and Environmental Sciences, 33: 21-30

Pham, T. H, D. T. N. Anh, D. T. Nha, D. H. Hai and H. T. T. Huong 2018 Metal bioaccumulation in fishes and macro zooplankton in some lakes in Hanoi, Vietnam Journal of Science and Technology, 56: $96-103$

Schindler, D. W 1977 Evolution of Phosphorus Limitation in Lakes, Science, 195: 260-62

Tran, V. T 2011 Researching and evaluating the current situation of water pollution and toxic algae in Nui Coc Lake (Thai Nguyen); proposing solutions for integrated management of lake water, Institute of Environmental Technology, Hanoi, DTDT. 2009/T08

WHO 2002 Eutrophication and health (Office for Official Publications of the European) 